\title{
Article \\ Exogenous Hemin Confers Cadmium Tolerance by Decreasing Cadmium Accumulation and Modulating Water Status and Matter Accumulation in Maize Seedlings
}

\author{
Xiaoming Liu ${ }^{1,+}$, Yao Meng ${ }^{2, \dagger}$, Shi Wei ${ }^{1}$ and Wanrong Gu ${ }^{1, *}$ \\ 1 College of Agriculture, Northeast Agricultural University, Harbin 150030, China; \\ liuxiaoming0913@163.com (X.L.); weishi5608@126.com (S.W.) \\ 2 Scientific Research Management Department, Heilongiiang Academy of Land Reclamation Sciences, \\ Harbin 150038, China; mengyao830922@163.com \\ * Correspondence: wanronggu@neau.edu.cn; Tel.: +86-451-551-90472 \\ + These authors contributed equally to this work.
}

Citation: Liu, X.; Meng, Y.; Wei, S.; $\mathrm{Gu}, \mathrm{W}$. Exogenous Hemin Confers Cadmium Tolerance by Decreasing Cadmium Accumulation and Modulating Water Status and Matter Accumulation in Maize Seedlings. Agronomy 2021, 11, 739. https:// doi.org/10.3390/agronomy11040739

Academic Editor: Alessio Aprile

Received: 7 March 2021

Accepted: 7 April 2021

Published: 10 April 2021

Publisher's Note: MDPI stays neutral with regard to jurisdictional claims in published maps and institutional affiliations.

Copyright: () 2021 by the authors. Licensee MDPI, Basel, Switzerland. This article is an open access article distributed under the terms and conditions of the Creative Commons Attribution (CC BY) license (https:// creativecommons.org/licenses/by/ $4.0 /)$.

\begin{abstract}
Cadmium (Cd) contamination harms plant growth and human health. The application of hemin (ferroprotoporphyrin IX) can effectively relieve abiotic stresses in plants. This work investigates the effects of hemin on alleviating $\mathrm{Cd}$ toxicity and enhancing $\mathrm{Cd}$ tolerance in maize seedlings. In this study, maize seedlings were cultivated in nutrient solutions, with a combination of $\mathrm{CdCl}_{2}\left(464 \mu \mathrm{mol} \mathrm{L}{ }^{-1}\right)$ and hemin $(100 \mu \mathrm{mol} \mathrm{L}-1)$. We measured plant growth status, water status, $\mathrm{Cd}$ concentration, and $\mathrm{Cd}$ distribution in maize seedlings. The results indicated that $\mathrm{Cd}$ stress increased $\mathrm{Cd}$ accumulation in plants and inhibited plant growth. However, hemin alleviated the growth inhibition and improved water balance, root morphology, and root vitality under Cd stress. Additionally, hemin increased 2,4-dihydroxy-7-methoxy-1,4-benzoxazin-3-one (DIMBOA), total phenolic content, and phenylalanine ammonia lyase (PAL) activity to enhance tolerance to $\mathrm{Cd}$ stress. Hemin reduced Cd concentration, the translocation factor (TF), and the bioconcentration factor (BCF) in maize seedlings under Cd stress. Furthermore, hemin increased Cd concentrations in the cell wall and the soluble fraction of seedling roots, which helped reduce Cd transport from root to shoot. In summary, exogenous hemin could be used for alleviating adverse impacts on maize seedling induced by Cd stress.
\end{abstract}

Keywords: maize; hemin; cadmium tolerance; water status; matter accumulation

\section{Introduction}

Cadmium (Cd) is one of the most hazardous and widespread environmental contaminants [1,2]. Cd is increasingly seriously exposed to the ecological system due to the influence of human activities like industrial waste emissions, sewage irrigation, and unreasonable fertilizer application in agricultural production [3,4]. Plants grown on Cdcontaminated soils can easily absorb $\mathrm{Cd}$ through their roots, and $\mathrm{Cd}$ can accumulate in other parts of the plant due to Cd's high mobility and availability in soil [5]. High Cd concentrations in plants inhibit plant growth and lead to a potential detriment to human health through the food chain cycle [6]. Humans ingesting Cd-contaminated food over a long time will easily accumulate $\mathrm{Cd}$ content above the safety margin. Therefore, it is essential for food security and human health to alleviate the negative impacts of $\mathrm{Cd}$ on plant growth and restrict $\mathrm{Cd}$ absorption and accumulation in plants under $\mathrm{Cd}$ stress.

High Cd content in crops produces a series of toxic effects, thus reducing agricultural yield and quality [7]. As is well known, plant roots are in direct contact with Cdcontaminated soil, and their growth will be severely inhibited; accordingly, this impairs the absorption of water and nutrients by plant roots [8]. High Cd concentrations in plants cause a reduction of photosynthetic pigment content and enzyme activities and stomatal 
conductance, resulting in an inhibition of photosynthesis and a decrease in plant stature and biomass $[9,10]$. Moreover, $\mathrm{Cd}$ stress causes severe damage to the cell membrane structure and antioxidant system, thereby destroying plant growth [11]. Much effort has been devoted to exploring approaches to alleviate excess $\mathrm{Cd}$ toxicity in plants. Exogenous application is one of the most effective approaches to alleviating the negative effects of $\mathrm{Cd}$ toxicity. For example, exogenous melatonin improves $\mathrm{Cd}$ tolerance by regulating the antioxidant systems in wheat seedlings [12]. Chitosan alleviates the growth inhibition of the root system, improving antioxidant enzyme activities and enhancing the photosynthesis of plants under Cd stress [13].

Hemin (ferroprotoporphyrin IX) is a metal porphyrin compound that is formed by the complexation of a molecule of ferrous iron and protoporphyrin [14]. Over the past few years, hemin has been widely used in multiple industries in safe artificial pigments [15], iron supplements [16], and pharmaceutical materials [17]. Recently, many studies have shown that exogenously applied hemin effectively relieves the adverse effects of abiotic stresses in various plants. For example, hemin treatment alleviates the inhibition of root elongation caused by salt stress, which enhances the tolerance to salt toxicity in wheat [18]. Exogenous applications of hemin significantly alleviated the oxidative damage triggered by Cd stress in Medicago sativa [19]. The role of hemin in increasing photosynthetic activity, decreasing $\mathrm{Cd}$ accumulation, and improving plant growth has also been reported in rice seedlings [20].

Maize is one of the major cereal crops in the world; it greatly contributes to food crop production [21]. In recent years, soil Cd contamination has become increasingly severe. High levels of $\mathrm{Cd}$ in maize have destroyed the growth and development of maize and decreased the grain's nutritional quality, causing a further threat to human health $[22,23]$. Therefore, efforts to impede $\mathrm{Cd}$ absorption and transport from soil to plants and reduce $\mathrm{Cd}$ accumulation in the aboveground fraction are crucial for alleviating $\mathrm{Cd}$ toxicity in maize and safeguarding human health. One of the most effective means to alleviating $\mathrm{Cd}$ toxicity in plants is applying exogenous additives. The beneficial role of hemin against $\mathrm{Cd}$ toxicity has been reported in previous studies [24,25]. However, they have mostly focused on the role of improving shoot and root growth and enhancing antioxidative capacity $[25,26]$. There are few studies on the effect of exogenously applied hemin on growth, root characteristics, $\mathrm{Cd}$ accumulation, translocation, and subcellular distribution in maize seedlings under $\mathrm{Cd}$ stress. This study aims to reveal the response and mitigation mechanism of hemin on maize seedlings under $\mathrm{Cd}$ stress, providing an experimental basis for improving plant growth and enhancing the tolerance of maize to $\mathrm{Cd}$ stress.

\section{Materials and Methods}

\subsection{Plant Growth Conditions and Treatments}

Maize seeds (Zea may L., cultivar Tiannong 9) were sterilized with 10\% sodium hypochlorite for $10 \mathrm{~min}$ and then rinsed with distilled water. The seeds were soaked in distilled water for $7 \mathrm{~h}$ and then germinated on wet filter paper in the dark at $25^{\circ} \mathrm{C}$ for $48 \mathrm{~h}$. The germinated seeds were transferred to a growth chamber where the temperature was set to $28 / 25^{\circ} \mathrm{C}$, corresponding to a $12 \mathrm{~h} / 12 \mathrm{~h}$ (day/night) photoperiod. Light intensity was kept at $400 \mu \mathrm{mol} \mathrm{m}{ }^{-2} \mathrm{~s}^{-1}$, and relative humidity was maintained at $60-70 \%$. After the first two leaves were fully expanded, uniform-germinated seedlings were selected and sown in plastic pots containing 1/2-strength Hoagland nutrient solution (40 L, $\mathrm{pH} 6.8$ ). The nutrient solution was renewed every 3 days. When the seedlings fully expanded their third leaf, 4 treatments were established as follows: (1) 1/2-strength Hoagland nutrient solution (CK); (2) 1/2-strength Hoagland nutrient solution $+100 \mu \mathrm{mol} \mathrm{L}^{-1}$ hemin (Hemin); (3) $1 / 2$-strength Hoagland nutrient solution $+464 \mu \mathrm{mol} \mathrm{L}^{-1} \mathrm{CdCl}_{2}(\mathrm{Cd})$; (4) $1 / 2$-strength Hoagland nutrient solution $+464 \mu \mathrm{mol} \mathrm{L}^{-1} \mathrm{CdCl}_{2}+100 \mu \mathrm{mol} \mathrm{L}^{-1}$ hemin $(\mathrm{Hemin}+\mathrm{Cd})$. Each treatment contained 3 replicates with 30 plants ( 90 plants in total). The seedlings were cultured for 4 days after the treatments and collected for measurement. 


\subsection{Determination of Plant Growth and Root Characteristic Parameters}

The plants were separated into roots and shoots after 4 days of treatment. The leaf area was recorded by leaf meter (SHY-150, Harbin, China). The root/shoot ratio was calculated as dry root weight/dry shoot weight. The root characteristic parameters, including root length, surface area, volume, mean diameter, and the number of root tips, were scanned using a root scanner (MRS-9600TFU2L, Shanghai, China). To determine dry weight, the roots and shoots were oven-dried at $105^{\circ} \mathrm{C}$ for $0.5 \mathrm{~h}$ and dried to constant weight at $80^{\circ} \mathrm{C}$.

\subsection{Determination of Leaf Relative Water Content and Leaf Water Potential}

To measure relative water content (RWC), the second fully expanded leaf per replicate was collected and weighed to estimate fresh weight. After that, leaf samples were immediately immersed in distilled water for $24 \mathrm{~h}$ in the dark to determine turgid weight. Finally, the samples were dried at $80^{\circ} \mathrm{C}$ for $48 \mathrm{~h}$ to determine dry weight. The following formula was used to calculate RWC: RWC $(\%)=($ fresh weight - dry weight $) /($ turgid weight - dry weight) $\times 100$.

The second fully expanded leaf's water potential ( $\Psi$ w) was measured using a 3115 pressure chamber (Beijing, China) system. Pressure was applied to the leaf surface in the chamber; when water began to appear at the cut end of the leaf's midrib, the pressure value was recorded as leaf $\Psi \mathrm{w}$.

\subsection{Determination of Root Hydraulic Conductance}

Each shoot was cut off at the base of the root system, leaving $4 \mathrm{~cm}$ of stem, and sealed with silicone seals. Thereafter, the whole root was placed in a pressure chamber. The pressure was raised in steps of $0.1 \mathrm{MPa}$ up to $0.4 \mathrm{MPa}$. The sap was collected with absorbent cotton at each pressure gradient (for $1 \mathrm{~min}$ ) and then weighed, generating a range of sap flows that represent the whole-plant. Root hydraulic conductance (Lp) was determined according to the following equation: $\mathrm{Lp}=\mathrm{Jv} / \mathrm{P}$, where $\mathrm{Jv}\left(\mathrm{m} \mathrm{s}^{-1}\right)$ and $\mathrm{P}(\mathrm{MPa})$ indicated the flow rate and external pressure, respectively [27].

\subsection{Determination of Root Vitality and the Root Length Stress Tolerance Index}

Root vitality was determined using triphenyltetrazolium chloride (TTC) [28]. The roots were cut into small pieces and incubated in the solution containing $5 \mathrm{~mL} 0.4 \%$ TTC and $0.1 \mathrm{M}$ PBS (pH 7.0) for $1 \mathrm{~h}$ at $37^{\circ} \mathrm{C}$. Then, we added $20 \mathrm{~mL}$ methanol, followed by incubation for $6 \mathrm{~h}$ at $37^{\circ} \mathrm{C}$. The total extracted solution was determined at the absorbance of $485 \mathrm{~nm}$. The Root Length Stress Tolerance Index (RLSI) was calculated following the method in [29]: root length of treatment plant/root length of control plant.

\subsection{Determination of $\mathrm{Cd}$ Concentration, the Translocation Factor, and the Bioconcentration Factor}

After $4 \mathrm{~d}$ of treatments, the powdery dried plant parts (shoots and roots) were used to determine $\mathrm{Cd}$ concentrations. The powders $(0.2 \mathrm{~g})$ were digested with mixed acid $\left(\mathrm{HNO}_{3} / \mathrm{HClO}_{4}, v / v=4 / 1\right)$ at $220^{\circ} \mathrm{C}$ for $4 \mathrm{~h}$ and then diluted to $25 \mathrm{~mL}$. The $\mathrm{Cd}$ concentration was then determined by an Optima3000 ICP-AES instrument (Perkin-Elmer, Waltham, MA, USA).

The translocation factor (TF) was calculated following the method in [30]: Cd concentration in shoots/Cd concentration in roots. The bioconcentration factor (BCF) was calculated following the method in [31]: Cd concentration in the aerial part of the plant/Cd concentration in the nutrient solution.

\subsection{Determination of Nonprotein Thiol and Phytochelatin Contents}

Fresh leaf samples $(1 \mathrm{~g})$ were ground in liquid nitrogen and homogenized in $8 \mathrm{~mL} 5 \%$ sulfosalicylic acid. The homogenate was centrifuged at $10,000 \times g$ at $4{ }^{\circ} \mathrm{C}$ for $15 \mathrm{~min}$, and the supernatant was collected for determination. Nonprotein thiol (NPT) and GSH were determined according to the method of Rama Devi [32] and Li [33], respectively. The amount of phytochelatins (PCs) was calculated using the following formula: PCs $=$ NPT - GSH. 


\subsection{Determination of Subcellular Cd Distribution}

Fresh samples were homogenized with precooled extraction buffer, and then the homogenate was filtered using nylon cloth, and the filtrate was centrifuged at $5000 \times g$ for $20 \mathrm{~min}$. The cell wall fraction was the deposit of the two operations. Next, the supernatant was centrifuged at $15,000 \times g$ for $45 \mathrm{~min}$ - the deposit was the cell organelle fraction, and the supernatant was the soluble fraction. Finally, these fractions were dried and digested with $\mathrm{HNO} 3 / \mathrm{HClO} 4(v / v=4 / 1)$. The $\mathrm{Cd}$ concentration in each fraction was determined by ICP-MS [34].

\subsection{Determination of Total Phenolic and 2,4-Dihydroxy-7-Methoxy-1,4-Benzoxazin-3-One (DIMBOA) Contents and Phenylalanine Ammonia Lyase (PAL) Activity}

The samples were ground to a fine powder under liquid nitrogen and then $5 \mathrm{~mL}$ water was added to incubate for $1 \mathrm{~h}$ at room temperature. After centrifugation, the supernatant was collected and extracted four times with an equal volume of ethyl acetate (EtOAc). Pooled extracts were evaporated, followed by dissolving the solid residue in $1.0 \mathrm{~mL}$ of $\mathrm{MeOH}$ for HPLC analysis. Analyses were performed using an Agilent $1100 \mathrm{HPLC}$. The mobile phase was $25 \%$ methanol and $75 \%$ acetic acid solution ( $\mathrm{pH} 2.6)$. The mobile phase flow rate was $1 \mathrm{~mL} \mathrm{~min}^{-1}$, and the total analysis time was $20 \mathrm{~min}$. The sample injection volume was $20 \mu \mathrm{L}$, and the detection wavelength was monitored at $262 \mathrm{~nm}$. The DIMBOA content was calculated by using the absorption peak areas of different concentrations of DIMBOA standard samples as a standard curve [35].

The samples were extracted with $10 \mathrm{~mL}$ of $70 \%(v / v)$ ethanol containing $1 \%$ hydrochloric acid and then centrifuged, and the extract was obtained after filtering. Extracts were thoroughly mixed with $1 \mathrm{~mL}$ Folin-Ciocalteu reagent. After standing for $10 \mathrm{~min}, 0.5 \mathrm{~mL}$ $7.5 \% \mathrm{Na}_{2} \mathrm{CO}_{3}$ was added to the mixture. Spectrophotometric measurements were done at $765 \mathrm{~nm}$. Content of total phenolics was calculated using gallic acid as standard [36].

The samples were homogenized in liquid nitrogen and extracted with $6 \mathrm{~mL}$ of sodium borate buffer $\left(0.05 \mathrm{~mol} \mathrm{~L}^{-1}, \mathrm{pH} 8.8\right.$, containing $5 \mathrm{mmol} \mathrm{L}^{-1}$ 2-mercaptoethanol, $1 \mathrm{mmol} \mathrm{L}{ }^{-1}$ EDTA, $0.2 \mathrm{~g}$ PVP). The homogenate was centrifuged at $10,000 \times \mathrm{g}$ for $15 \mathrm{~min}$ at $4{ }^{\circ} \mathrm{C}$ to obtain the supernatant. PAL activity was determined at the absorbance of $290 \mathrm{~nm}[37]$.

\subsection{Statistical Analysis}

The data were summarized to calculate mean value and standard error (SE). The mean value was compared by analysis of variance (ANOVA) to analyze the significant differences between samples with different treatments $(p<0.05)$. All statistical analyses were performed using SPSS 19.0 procedures (SPSS Inc., Chicago, IL, USA). Microsoft Excel 2010 was used to draw the tables.

\section{Results}

\subsection{Seedling Growth}

The results of the impact of different treatments on the growth traits of maize seedlings are presented in Table 1 . In the absence of Cd stress, the application of hemin increased maize seedling leaf area, dry shoot weight, dry root weight, and root/shoot ratio, but the difference was not significant except for dry shoot weight. Compared with CK, Cd stress significantly inhibited seedling growth and decreased leaf area, dry shoot weight, and dry root weight by $20.99 \%, 23.68 \%$, and $13.27 \%$, respectively. Applying hemin significantly alleviated the growth inhibition caused by $\mathrm{Cd}$ and increased leaf area, dry shoot weight, and dry root weight. Hemin treatment had different effects on the root/shoot ratio under $\mathrm{Cd}$ stress. Cd stress significantly increased the root/shoot ratio, while hemin application reduced the root/shoot ratio by $5.49 \%$ compared with Cd stress. 
Table 1. Effects of hemin on leaf area, dry shoot weight, dry root weight, and the root/shoot ratio under Cd stress.

\begin{tabular}{|c|c|c|c|c|}
\hline Treatments & $\begin{array}{c}\text { Leaf Area } \\
\left(\mathrm{cm}^{2} \text { plant }^{-1}\right)\end{array}$ & $\begin{array}{l}\text { Dry Shoot Weight } \\
\quad\left(\mathrm{g} \mathrm{plant}^{-1}\right)\end{array}$ & $\begin{array}{l}\text { Dry Root Weight } \\
\quad\left(\mathrm{g} \mathrm{plant}^{-1}\right)\end{array}$ & $\begin{array}{c}\text { Root/Shoot } \\
\text { Ratio }\end{array}$ \\
\hline CK & $86.232 \pm 2.212 \mathrm{a}$ & $0.342 \pm 0.032 b$ & $0.211 \pm 0.031 \mathrm{ab}$ & $0.632 \pm 0.011 \mathrm{c}$ \\
\hline Hemin & $91.451 \pm 2.083 \mathrm{a}$ & $0.352 \pm 0.025 \mathrm{a}$ & $0.222 \pm 0.031 \mathrm{a}$ & $0.642 \pm 0.022 c$ \\
\hline $\mathrm{Cd}$ & $68.134 \pm 1.642 c$ & $0.261 \pm 0.046 \mathrm{~d}$ & $0.183 \pm 0.025 c$ & $0.711 \pm 0.011 \mathrm{a}$ \\
\hline Hemin $+\mathrm{Cd}$ & $76.543 \pm 1.352 b$ & $0.293 \pm 0.042 c$ & $0.191 \pm 0.034 \mathrm{~b}$ & $0.672 \pm 0.022 b$ \\
\hline
\end{tabular}

The maize seedlings were treated with control (CK), $100 \mu \mathrm{mol} \mathrm{L}^{-1}$ hemin (Hemin), $464 \mu \mathrm{mol} \mathrm{L}{ }^{-1} \mathrm{CdCl}_{2}(\mathrm{Cd}), 100 \mu \mathrm{mol} \mathrm{L} \mathrm{L}^{-1}$ hemin $+464 \mu \mathrm{mol} \mathrm{L}^{-1} \mathrm{CdCl}_{2}($ Hemin $+\mathrm{Cd})$ for $4 \mathrm{~d}$. Values are mean $\pm \mathrm{SD}(\mathrm{n}=3)$. Different letters within a column indicate significant differences at $p<0.05$, as determined by Duncan's multiple range test.

\subsection{RWC and $\Psi w$ and $L p$}

From 1 to $4 \mathrm{~d}$ after $\mathrm{Cd}$ treatment, leaf $\Psi \mathrm{w}$ and RWC values of maize seedlings showed an overall downward trend. In the absence of Cd stress, the application of hemin had no significant effect on $\Psi_{w}$ and RWC. Compared with CK, leaf $\Psi_{w}$ and RWC decreased by $128.14 \%$ and $28.63 \%$, respectively, after 4 days of Cd stress. Hemin reduced Cd's adverse effects on leaf $\Psi_{\mathrm{w}}$ and RWC and increased leaf $\Psi_{\mathrm{w}}$ and RWC by $15.94 \%$ and $11.52 \%$, respectively. Hemin treatment had a similar impact on Lp under Cd stress. Cd stress significantly reduced Lp, while hemin application increased Lp by $29.74 \%$ compared with Cd stress (Table 2).

Table 2. Effects of hemin on leaf relative water content (RWC), leaf water potential ( $\Psi w)$, and root hydraulic conductance (Lp) under Cd stress.

\begin{tabular}{|c|c|c|c|c|c|c|}
\hline \multirow[t]{2}{*}{ Characters } & \multirow[t]{2}{*}{ Treatments } & \multicolumn{5}{|c|}{ Days after Treatments (d) } \\
\hline & & $\mathbf{0}$ & 1 & 2 & 3 & 4 \\
\hline \multirow[t]{4}{*}{ RWC (\%) } & CK & $92.69 \pm 1.12 \mathrm{a}$ & $93.30 \pm 1.20 \mathrm{a}$ & $91.20 \pm 1.20 \mathrm{a}$ & $90.66 \pm 1.30 \mathrm{a}$ & $89.37 \pm 1.20 \mathrm{a}$ \\
\hline & Hemin & $93.50 \pm 1.20 \mathrm{a}$ & $92.40 \pm 1.30 \mathrm{a}$ & $90.60 \pm 1.10 \mathrm{a}$ & $89.54 \pm 1.20 \mathrm{a}$ & $90.16 \pm 1.10 \mathrm{a}$ \\
\hline & $\mathrm{Cd}$ & $91.20 \pm 1.30 \mathrm{a}$ & $82.30 \pm 1.20 \mathrm{~b}$ & $77.20 \pm 1.10 c$ & $70.30 \pm 1.30 c$ & $63.20 \pm 1.13 c$ \\
\hline & Hemin $+\mathrm{Cd}$ & $91.30 \pm 1.57 \mathrm{a}$ & $85.40 \pm 1.10 \mathrm{ab}$ & $80.30 \pm 1.02 \mathrm{~b}$ & $74.60 \pm 1.20 \mathrm{~b}$ & $72.20 \pm 1.20 \mathrm{~b}$ \\
\hline \multirow[t]{4}{*}{$\Psi \mathrm{w}(\mathrm{MPa})$} & CK & $-0.73 \pm 0.04 \mathrm{a}$ & $-0.72 \pm 0.02 \mathrm{a}$ & $-0.74 \pm 0.02 \mathrm{a}$ & $-0.76 \pm 0.02 \mathrm{a}$ & $-0.78 \pm 0.03 a$ \\
\hline & Hemin & $-0.74 \pm 0.03 \mathrm{a}$ & $-0.72 \pm 0.03 \mathrm{a}$ & $-0.75 \pm 0.02 \mathrm{a}$ & $-0.72 \pm 0.03 \mathrm{a}$ & $-0.67 \pm 0.03 \mathrm{a}$ \\
\hline & $\mathrm{Cd}$ & $-0.74 \pm 0.02 \mathrm{a}$ & $-1.32 \pm 0.01 c$ & $-1.52 \pm 0.03 c$ & $-1.69 \pm 0.02 c$ & $-1.74 \pm 0.04 c$ \\
\hline & Hemin $+\mathrm{Cd}$ & $-0.75 \pm 0.03 \mathrm{a}$ & $-0.98 \pm 0.02 b$ & $-1.23 \pm 0.02 b$ & $-1.46 \pm 0.02 b$ & $-1.62 \pm 0.02 b$ \\
\hline \multirow[t]{4}{*}{$\begin{array}{c}\mathrm{Lp}\left(10^{-8} \mathrm{~m} \mathrm{~s}^{-1}\right. \\
\left.\mathrm{MPa}^{-1}\right)\end{array}$} & CK & $10.80 \pm 0.18 \mathrm{a}$ & $11.10 \pm 0.16 \mathrm{a}$ & $11.20 \pm 0.16 \mathrm{a}$ & $9.80 \pm 0.16 \mathrm{a}$ & $9.60 \pm 0.17 \mathrm{a}$ \\
\hline & Hemin & $11.20 \pm 0.17 \mathrm{a}$ & $11.50 \pm 0.17 \mathrm{a}$ & $12.40 \pm 0.16 \mathrm{a}$ & $10.80 \pm 0.17 \mathrm{a}$ & $10.40 \pm 0.17 \mathrm{a}$ \\
\hline & $\mathrm{Cd}$ & $10.90 \pm 0.16 \mathrm{a}$ & $9.50 \pm 0.15 b$ & $7.80 \pm 0.17 c$ & $7.50 \pm 0.16 c$ & $6.70 \pm 0.18 c$ \\
\hline & Hemin $+\mathrm{Cd}$ & $11.30 \pm 0.17 \mathrm{a}$ & $10.50 \pm 0.16 \mathrm{ab}$ & $9.20 \pm 0.16 b$ & $8.70 \pm 0.16 b$ & $7.90 \pm 0.16 b$ \\
\hline
\end{tabular}

The maize seedlings were treated with control (CK), $100 \mu \mathrm{mol} \mathrm{L}^{-1}$ hemin (Hemin), $464 \mu \mathrm{mol} \mathrm{L}^{-1} \mathrm{CdCl}_{2}(\mathrm{Cd}), 100 \mu \mathrm{mol} \mathrm{L}{ }^{-1}$ hemin $+464 \mu \mathrm{mol} \mathrm{L}^{-1} \mathrm{CdCl}_{2}($ Hemin $+\mathrm{Cd})$ for $0-4 \mathrm{~d}$. Values are mean $\pm \mathrm{SD}(\mathrm{n}=3)$. Different letters within a column indicate significant differences at $p<0.05$, as determined by Duncan's multiple range test.

\subsection{Root Traits}

In the absence of $\mathrm{Cd}$ stress, the application of hemin significantly increased root surface area, length, and diameter. Cd stress inhibited root growth, leading to $19.7 \%, 23.4 \%$, $26.1 \%, 23.8 \%$, and $32.8 \%$ decreases in root length, surface area, volume, mean diameter, and number of root tips, respectively. Hemin significantly relieved the inhibition of root growth under $\mathrm{Cd}$ stress and increased root length, surface area, volume, mean diameter, and number of root tips by $12.48 \%, 15.05 \%, 18.49 \%, 15.15 \%$, and $27.03 \%$, respectively. In the absence of $\mathrm{Cd}$ stress, the application of hemin significantly improved root vitality. $\mathrm{Cd}$ stress reduced root vitality by $47.3 \%$ compared with CK. Hemin alleviated the Cd-induced constraint of root vitality and increased root vitality by $55.9 \%$. The values of RLSI in $\mathrm{Cd}$ treatment and Hemin $+\mathrm{Cd}$ treatment were 0.8 and 0.9 , respectively. Therefore, the application of hemin significantly increased RLSI under Cd stress (Table 3). 
Table 3. Effects of hemin on root morphological traits (root length, surface area, volume, mean diameter, and number of root tips), root vitality and the root length stress tolerance index (RLSI) under Cd stress.

\begin{tabular}{|c|c|c|c|c|c|c|c|}
\hline Treatments & $\begin{array}{l}\text { Root Length } \\
\left(\mathrm{cm}_{\text {plant }}{ }^{-1}\right)\end{array}$ & $\begin{array}{c}\text { Root Surface } \\
\text { Area } \\
\left(\mathrm{cm}^{2} \text { plant }^{-1}\right)\end{array}$ & $\begin{array}{l}\text { Root Volume } \\
\left(\mathrm{cm}^{3} \text { plant }^{-1}\right)\end{array}$ & $\begin{array}{l}\text { Root Average } \\
\text { Diameter } \\
(\mathrm{mm})\end{array}$ & $\begin{array}{l}\text { Root Tips } \\
\text { Number } \\
\left(\text { plant }^{-1}\right)\end{array}$ & $\begin{array}{l}\text { Root Vitality } \\
\left(\mu g g^{-1} h^{-1}\right)\end{array}$ & RLSI \\
\hline CK & $311.8 \pm 2.2 \mathrm{~b}$ & $77.01 \pm 2.21 \mathrm{~b}$ & $3.53 \pm 0.01 \mathrm{a}$ & $0.84 \pm 0.01 \mathrm{~b}$ & $342.55 \pm 4.2 \mathrm{a}$ & $54.20 \pm 1.0 \mathrm{~b}$ & - \\
\hline Hemin & $380.3 \pm 4.5 \mathrm{a}$ & $81.04 \pm 2.14 \mathrm{a}$ & $3.74 \pm 0.03 \mathrm{a}$ & $0.93 \pm 0.01 \mathrm{a}$ & $374.12 \pm 3.3 \mathrm{a}$ & $62.40 \pm 1.1 \mathrm{a}$ & $1.22 \pm 0.01 \mathrm{a}$ \\
\hline $\mathrm{Cd}$ & $250.1 \pm 3.0 \mathrm{~d}$ & $58.33 \pm 1.71 \mathrm{~d}$ & $2.65 \pm 0.01 \mathrm{c}$ & $0.66 \pm 0.01 \mathrm{~d}$ & $230.33 \pm 3.0 \mathrm{c}$ & $28.56 \pm 1.1 \mathrm{~d}$ & $0.80 \pm 0.01 c$ \\
\hline Hemin $+\mathrm{Cd}$ & $281.3 \pm 4.1 \mathrm{c}$ & $67.11 \pm 1.82 \mathrm{c}$ & $3.14 \pm 0.03 b$ & $0.76 \pm 0.02 c$ & $292.58 \pm 4.2 b$ & $43.87 \pm 1.4 c$ & $0.90 \pm 0.01 b$ \\
\hline
\end{tabular}

The maize seedlings were treated with control (CK), $100 \mu \mathrm{mol} \mathrm{L}{ }^{-1}$ hemin (Hemin), $464 \mu \mathrm{mol} \mathrm{L}^{-1} \mathrm{CdCl}_{2}(\mathrm{Cd}), 100 \mu \mathrm{mol} \mathrm{L}{ }^{-1}$ hemin $+464 \mu \mathrm{mol} \mathrm{L}^{-1} \mathrm{CdCl}_{2}($ Hemin $+\mathrm{Cd})$ for $4 \mathrm{~d}$. Values are mean $\pm \mathrm{SD}(\mathrm{n}=3)$. Different letters within a column indicate significant differences at $p<0.05$, as determined by Duncan's multiple range test.

\subsection{Cd Concentrations and Translocation}

We measured $\mathrm{Cd}$ concentrations in root, shoot, and whole seedling in each treatment. Under Cd stress, the $\mathrm{Cd}$ concentration in roots was higher than shoots. The application of hemin impeded the accumulation of $\mathrm{Cd}$ in the plants. Compared to $\mathrm{Cd}$ treatment, the $\mathrm{Cd}$ concentrations in root, shoot, and seedling in the Hemin $+\mathrm{Cd}$ treatment were decreased by $13.12 \%, 33.8 \%$, and $19.97 \%$, respectively. The application of hemin inhibited $\mathrm{Cd}$ translocation from underground to shoot. The Hemin $+\mathrm{Cd}$ treatment decreased TF and BCF by $23.73 \%$ and $33.83 \%$, respectively (Table 4 ).

Table 4. Effects of hemin on Cd concentrations of shoot and root, total Cd concentration, the translocation factor (TF), and the bioconcentration factor (BCF) under Cd stress.

\begin{tabular}{|c|c|c|c|c|c|}
\hline Treatments & $\begin{array}{l}\text { Cd Concentration in } \\
\text { Root }\left(\mathrm{mg} \mathrm{kg}^{-1} \mathrm{DW}\right)\end{array}$ & $\begin{array}{l}\text { Cd Concentration in } \\
\text { Shoot }\left(\mathrm{mg} \mathrm{kg}^{-1} \mathrm{DW}\right)\end{array}$ & $\begin{array}{c}\text { Total Cd } \\
\text { Concentration } \\
\left(\mathrm{mg} \mathrm{kg}^{-1} \mathrm{DW}\right)\end{array}$ & TF & BCF \\
\hline CK & - & - & - & - & - \\
\hline Hemin & - & - & - & - & - \\
\hline $\mathrm{Cd}$ & $405.36 \pm 8.25 \mathrm{a}$ & $200.03 \pm 7.27 \mathrm{a}$ & $605.39 \pm 8.56 \mathrm{a}$ & $0.493 \pm 0.01 \mathrm{a}$ & $2.353 \pm 0.06 a$ \\
\hline $\mathrm{Hemin}+\mathrm{Cd}$ & $352.14 \pm 6.87 b$ & $132.38 \pm 4.32 b$ & $484.52 \pm 7.27 b$ & $0.376 \pm 0.02 b$ & $1.557 \pm 0.07 \mathrm{~b}$ \\
\hline
\end{tabular}

The maize seedlings were treated with control (CK), $100 \mu \mathrm{mol} \mathrm{L}-1$ hemin (Hemin), $464 \mu \mathrm{mol} \mathrm{L}^{-1} \mathrm{CdCl}_{2}(\mathrm{Cd}), 100 \mu \mathrm{mol} \mathrm{L}-1$ hemin $+464 \mu \mathrm{mol} \mathrm{L}^{-1} \mathrm{CdCl}_{2}($ Hemin $+\mathrm{Cd})$ for $4 \mathrm{~d}$. Values are mean $\pm \mathrm{SD}(\mathrm{n}=3)$. Different letters within a column indicate significant differences at $p<0.05$, as determined by Duncan's multiple range test.

\subsection{NPT and PC Contents}

Hemin treatment observably increased NPT and PC contents of leaf and root compared with CK. Cd treatment also increased NPT and PC contents compared with CK. The application of Hemin further increased the contents of NPT and PCs in seedlings. Compared with Cd treatment, the Hemin + Cd treatment increased NPT and PC contents by $39.1 \%$ and $69.7 \%$ in leaf and $58.1 \%$ and $63.1 \%$ in root, respectively (Table 5 ).

Table 5. Effects of hemin on nonprotein thiol (NPT) and phytochelatin (PC) contents of leaf and root under Cd stress.

\begin{tabular}{|c|c|c|c|c|}
\hline \multirow[b]{2}{*}{ Treatments } & \multicolumn{2}{|c|}{ Leaf } & \multicolumn{2}{|c|}{ Root } \\
\hline & $\begin{array}{l}\text { NPT Content } \\
\left(\mu \mathrm{mol} \mathrm{g}^{-1} \mathrm{FW}\right)\end{array}$ & $\begin{array}{c}\text { PC Content } \\
\left(\mu \mathrm{mol} \mathrm{g}{ }^{-1} \mathrm{FW}\right)\end{array}$ & $\begin{array}{l}\text { NPT Content } \\
\left(\mu \mathrm{mol} \mathrm{g}^{-1} \mathrm{FW}\right)\end{array}$ & $\begin{array}{c}\text { PCs Content } \\
\left(\mu \mathrm{mol} \mathrm{g}^{-1} \mathrm{FW}\right)\end{array}$ \\
\hline CK & $0.94 \pm 0.01 \mathrm{~d}$ & $0.27 \pm 0.02 \mathrm{~d}$ & $1.12 \pm 0.01 \mathrm{~d}$ & $0.48 \pm 0.01 \mathrm{~d}$ \\
\hline Hemin & $1.96 \pm 0.01 b$ & $0.82 \pm 0.02 b$ & $2.13 \pm 0.02 b$ & $1.56 \pm 0.01 b$ \\
\hline $\mathrm{Cd}$ & $1.61 \pm 0.01 \mathrm{c}$ & $0.66 \pm 0.01 c$ & $1.55 \pm 0.01 c$ & $1.22 \pm 0.01 \mathrm{c}$ \\
\hline Hemin $+\mathrm{Cd}$ & $2.24 \pm 0.01 \mathrm{a}$ & $1.12 \pm 0.01 \mathrm{a}$ & $2.45 \pm 0.01 \mathrm{a}$ & $1.99 \pm 0.02 \mathrm{a}$ \\
\hline
\end{tabular}

The maize seedlings were treated with control (CK), $100 \mu \mathrm{mol} \mathrm{L}{ }^{-1}$ hemin (Hemin), $464 \mu \mathrm{mol} \mathrm{L}-1 \mathrm{CdCl}_{2}(\mathrm{Cd}), 100 \mu \mathrm{mol} \mathrm{L}-1$ hemin $+464 \mu \mathrm{mol} \mathrm{L}{ }^{-1} \mathrm{CdCl}_{2}($ Hemin $+\mathrm{Cd})$ for $4 \mathrm{~d}$. Values are mean $\pm \mathrm{SD}(\mathrm{n}=3)$. Different letters within a column indicate significant differences at $p<0.05$, as determined by Duncan's multiple range test. 


\subsection{Subcellular Distribution of $C d$}

Hemin has a significant influence on the distribution of $\mathrm{Cd}$ in subcellular fractions of maize leaf and root under Cd stress. In leaf, the Hemin $+\mathrm{Cd}$ treatment reduced $\mathrm{Cd}$ concentration in the soluble fraction and the organelle by $68.72 \%$ and $63.05 \%$ compared with $\mathrm{Cd}$ treatment, while $\mathrm{Cd}$ concentration in the cell wall increased, although not significantly. In root, the Hemin $+\mathrm{Cd}$ treatment increased $\mathrm{Cd}$ concentration in the soluble fraction and the cell wall by $92.4 \%$ and $118.7 \%$ compared with $\mathrm{Cd}$ treatment, while $\mathrm{Cd}$ concentration in the organelle decreased, although not significantly (Table 6).

Table 6. Effects of hemin on subcellular distribution (soluble fraction, cell organelle, and cell wall) of Cd in roots and shoots under Cd stress.

\begin{tabular}{|c|c|c|c|c|}
\hline \multirow{2}{*}{ Parts } & \multirow{2}{*}{ Treatments } & \multicolumn{3}{|c|}{ Cd Concentrations and Distributions of Subcellular Fractions ( $\left.\mathrm{mg} \mathrm{kg}^{-1} \mathrm{DW}\right)$} \\
\hline & & Soluble Fraction (Vacuole) & Cell Organelle & Cell Wall \\
\hline \multirow{4}{*}{ Leaf } & CK & - & - & - \\
\hline & Hemin & - & - & - \\
\hline & $\mathrm{Cd}$ & $68.28 \pm 2.12 \mathrm{a}$ & $11.23 \pm 0.31 \mathrm{a}$ & $15.23 \pm 0.33 \mathrm{a}$ \\
\hline & Hemin $+\mathrm{Cd}$ & $21.36 \pm 3.14 b$ & $4.15 \pm 0.12 \mathrm{~b}$ & $16.34 \pm 0.41 \mathrm{a}$ \\
\hline \multirow{4}{*}{ Root } & CK & - & - & - \\
\hline & Hemin & - & - & - \\
\hline & $\mathrm{Cd}$ & $241.87 \pm 3.65 b$ & $46.55 \pm 1.65 \mathrm{a}$ & $38.96 \pm 0.28 b$ \\
\hline & Hemin $+\mathrm{Cd}$ & $465.33 \pm 4.15 \mathrm{a}$ & $44.98 \pm 2.11 \mathrm{a}$ & $85.24 \pm 0.31 \mathrm{a}$ \\
\hline
\end{tabular}

The maize seedlings were treated with control (CK), $100 \mu \mathrm{mol} \mathrm{L}{ }^{-1}$ hemin (Hemin), $464 \mu \mathrm{mol} \mathrm{L}-1 \mathrm{CdCl}_{2}(\mathrm{Cd}), 100 \mu \mathrm{mol} \mathrm{L}-1$ hemin $+464 \mu \mathrm{mol} \mathrm{L}^{-1} \mathrm{CdCl}_{2}($ Hemin $+\mathrm{Cd})$ for $4 \mathrm{~d}$. Values are mean $\pm \mathrm{SD}(\mathrm{n}=3)$. Different letters within a column indicate significant differences at $p<0.05$, as determined by Duncan's multiple range test.

\subsection{Total Phenolics, DIMBOA, and PAL Activity}

The contents of DIMBOA and total phenolics and PAL activity in roots were higher than those in leaves. In the absence of $\mathrm{Cd}$ stress, the application of hemin increased DIMBOA and total phenolic contents and PAL activity in roots and leaves on the second and fourth days after treatment. Cd stress significantly reduced the contents of DIMBOA and total phenolics and PAL activity compared with CK in the seedlings. However, the application of hemin counteracted the Cd-induced reduction of secondary metabolite contents and PAL activity. In root, the Hemin + Cd treatment increased DIMBOA content, total phenolics content, and PAL activity by $34.93 \%, 33.68 \%$, and $23.31 \%$ on the second day after treatment compared with Cd treatment and increased them by $51.47 \%, 49.50 \%$, and $33.33 \%$ on the fourth day after treatment, respectively. In leaf, the Hemin $+\mathrm{Cd}$ treatment increased DIMBOA content, total phenolic content, and PAL activity by $36.27 \%, 34.22 \%$, and $19.58 \%$ on the second day after treatment compared with Cd treatment and increased them by $74.91 \%, 70.28 \%$, and $39.90 \%$ on the fourth day after treatment, respectively (Table 7 ).

Table 7. Effects of hemin on 2,4-dihydroxy-7-methoxy-1,4-benzoxazin-3-one (DIMBOA) and total phenolic contents and phenylalanine ammonia lyase (PAL) activity in roots and shoots under Cd stress.

\begin{tabular}{|c|c|c|c|c|c|c|c|}
\hline \multirow[b]{2}{*}{ Parts } & \multirow[b]{2}{*}{ Treatments } & \multicolumn{3}{|c|}{$2 \mathrm{~d}$ after Treatments } & \multicolumn{3}{|c|}{$4 \mathrm{~d}$ after Treatments } \\
\hline & & $\begin{array}{c}\text { DIMBOA } \\
\left(\mu g g^{-1}\right)\end{array}$ & $\begin{array}{c}\text { Total } \\
\text { Phenolics } \\
\left(\mu g g^{-1}\right)\end{array}$ & $\begin{array}{c}\text { PAL } \\
\left(\mathrm{U} \mathrm{mg}^{-1} \mathrm{FW}\right)\end{array}$ & $\begin{array}{c}\text { DIMBOA } \\
\left(\mu g g^{-1}\right)\end{array}$ & $\begin{array}{c}\text { Total } \\
\text { Phenolics } \\
\left(\mu g^{-1}\right)\end{array}$ & $\begin{array}{c}\text { PAL } \\
\left(\mathrm{U} \mathrm{mg}^{-1} \mathrm{FW}\right)\end{array}$ \\
\hline \multirow{4}{*}{ Root } & CK & $113.4 \pm 3.2 c$ & $749.4 \pm 5.6 c$ & $21.0 \pm 0.8 c$ & $116.5 \pm 2.2 c$ & $1034.5 \pm 5.6 c$ & $29.9 \pm 0.9 c$ \\
\hline & Hemin & $155.2 \pm 4.2 \mathrm{a}$ & $1016.9 \pm 6.8 \mathrm{a}$ & $26.3 \pm 0.7 \mathrm{a}$ & $168.4 \pm 2.6 \mathrm{a}$ & $1480.8 \pm 4.8 \mathrm{a}$ & $39.2 \pm 0.4 \mathrm{a}$ \\
\hline & $\mathrm{Cd}$ & $100.5 \pm 2.6 \mathrm{~d}$ & $666.8 \pm 7.2 \mathrm{~d}$ & $19.3 \pm 1.1 \mathrm{~d}$ & $95.2 \pm 2.4 \mathrm{~d}$ & $851.3 \pm 7.6 \mathrm{~d}$ & $26.1 \pm 0.5 \mathrm{~d}$ \\
\hline & Hemin + Cd & $135.6 \pm 3.6 \mathrm{~b}$ & $891.4 \pm 6.8 \mathrm{~b}$ & $23.8 \pm 0.5 b$ & $144.2 \pm 3.4 \mathrm{~b}$ & $1272.7 \pm 5.9 \mathrm{~b}$ & $34.8 \pm 0.6 \mathrm{~b}$ \\
\hline \multirow{4}{*}{ Leaf } & CK & $72.3 \pm 2.1 c$ & $486.3 \pm 4.2 \mathrm{c}$ & $15.7 \pm 0.4 c$ & $79.8 \pm 2.1 \mathrm{c}$ & $718.9 \pm 3.9 c$ & $23.3 \pm 0.4 c$ \\
\hline & Hemin & $99.2 \pm 1.2 \mathrm{a}$ & $658.5 \pm 3.8 \mathrm{a}$ & $19.2 \pm 0.8 \mathrm{a}$ & $115.3 \pm 2.6 \mathrm{a}$ & $1024.2 \pm 2.1 \mathrm{a}$ & $29.7 \pm 0.6 \mathrm{a}$ \\
\hline & $\mathrm{Cd}$ & $61.2 \pm 2.5$ & $415.3 \pm 4.1 \mathrm{~d}$ & $14.3 \pm 0.7 \mathrm{~d}$ & $57.4 \pm 2.1 \mathrm{~d}$ & $526.2 \pm 5.4 \mathrm{~d}$ & $19.3 \pm 0.4 \mathrm{~d}$ \\
\hline & Hemin $+\mathrm{Cd}$ & $83.4 \pm 1.2 \mathrm{~b}$ & $557.4 \pm 3.7 \mathrm{~b}$ & $17.1 \pm 0.7 \mathrm{~b}$ & $100.4 \pm 3.1 \mathrm{~b}$ & $896.0 \pm 3.8 \mathrm{~b}$ & $27.0 \pm 0.3 b$ \\
\hline
\end{tabular}

The maize seedlings were treated with control (CK), $100 \mu \mathrm{mol} \mathrm{L}{ }^{-1}$ hemin (Hemin), $464 \mu \mathrm{mol} \mathrm{L}^{-1} \mathrm{CdCl}_{2}(\mathrm{Cd}), 100 \mu \mathrm{mol} \mathrm{L}-1$ hemin $+464 \mu \mathrm{mol} \mathrm{L}{ }^{-1} \mathrm{CdCl}_{2}($ Hemin $+\mathrm{Cd})$ for 2 or $4 \mathrm{~d}$. Values are mean $\pm \mathrm{SD}(\mathrm{n}=3)$. Different letters within a column indicate significant differences at $p<0.05$, as determined by Duncan's multiple range test. 


\section{Discussion}

Under Cd stress, plants often show growth inhibition and biomass reduction [38,39]. It has been reported that the suppression of plant growth is one of the most crucial characteristics in plants under Cd stress [40]. This study shows that $\mathrm{Cd}$ treatment significantly decreases leaf area, dry shoot weight, and dry root weight in maize seedlings. Hemin alleviated the $\mathrm{Cd}$-induced repression of maize growth in the presence of $\mathrm{Cd}$ stress. It has been reported that root morphology is an important indicator for evaluating $\mathrm{Cd}$ toxicity in plants. Cd exposure decreases total root length, number of root tips, and root radial expansion, which inhibit root growth and decrease plant root absorption capacity [41-43]. In this study, Cd stress reduced root length, root surface area, root volume, root average diameter, and the number of root tips. Exogenous hemin improved the characteristic parameters of the maize root system and increased root vitality and RLSI under Cd stress, which are beneficial for promoting the absorption of water and nutrients. Cd affects the permeability of the plasma membrane by inducing lipid peroxidation, leading to an imbalance between $\mathrm{Cd}$ and water and causing a water deficit [44]. Previous studies have shown that hemin reduces the active oxygen contents in plants under heavy metal stress and reduces lipid peroxidation induced by oxidative stress [26,45]. In this study, Cd stress decreased leaf RWC, leaf $\Psi \omega$, and root Lp. However, hemin enhanced water flow efficiency through maize roots and improved the water status in shoots, accordingly increasing the tolerance of maize seedlings under Cd stress.

Plants growing in Cd-contaminated soil can easily absorb and accumulate $\mathrm{Cd}$. $\mathrm{Cd}$ is harmful to plant growth, and crops that contain $\mathrm{Cd}$ threaten human food security through the food chain [46,47]. Therefore, reducing Cd accumulation is the key to alleviating $\mathrm{Cd}$ toxicity in plants. In this study, we found that exogenous hemin reduced the $\mathrm{Cd}$ concentration in the shoots and roots of maize seedlings under $\mathrm{Cd}$ stress. This result is consistent with another study that reduced $\mathrm{Cd}$ accumulation in Chinese cabbage seedlings by exogenous hemin [24]. At present, the mechanism of hemin reducing $\mathrm{Cd}$ accumulation in plants is not clear. Hemin is an inducer of HO1, which can induce the expression of HO1 [48]. The expression of HO1 has been shown to be beneficial in inhibiting the absorption and accumulation of heavy metals in Indian mustard [49]. HO1 can also specifically degrade heme to produce biliverdin, Fe, and CO. HY1(AtHO-1) might improve Fe homeostasis under Cd stress, thereby relieving Cd accumulation in Arabidopsis [50]. Han et al. [51] considered that $\mathrm{CO}$ could induce alfalfa tolerance against $\mathrm{Cd}$ toxicity. The mechanism of hemin reducing $\mathrm{Cd}$ absorption and accumulation in plants needs to be further explored.

Cd's chemical forms and subcellular distribution directly determine $\mathrm{Cd}$ activity in the cell and further reflect the plants' toxicity level $[52,53]$. NPTs and PCs are important heavy metal chelating agents in plants, which can chelate with Cd ions in the cytoplasm and then be transported to the vacuole to synthesize high molecular complexes with stable properties, thereby alleviating $\mathrm{Cd}$ toxicity $[54,55]$. In this study, NPT and PC contents increased under Cd stress. However, the NPT and PC contents in maize seedlings further increased after applying hemin under $\mathrm{Cd}$ stress. This indicates that hemin plays an important role in alleviating $\mathrm{Cd}$ toxicity in maize seedlings by increasing $\mathrm{Cd}$ ion chelation under $\mathrm{Cd}$ stress. Plant root cell walls are directly contacted with heavy metals dissolved in the soil solution, which is the outermost barrier to protect protoplasts from Cd toxicity $[56,57]$. The constituent of the root cell wall (such as pectin, hemicellulose, and protein) can combine with $\mathrm{Cd}$ and facilitate $\mathrm{Cd}$ deposit on the cell wall, thereby restraining $\mathrm{Cd}$ transport into the protoplast and reducing $\mathrm{Cd}$ toxicity $[58,59]$. In this study, exogenous hemin increased $\mathrm{Cd}$ concentration in the root cell wall, which enhanced the detoxification ability of maize seedlings under $\mathrm{Cd}$ exposure. Moreover, hemin improved $\mathrm{Cd}$ transport from protoplasts to vacuoles by increasing $\mathrm{Cd}$ concentration in the soluble fraction of maize roots. $\mathrm{Cd}$ concentration in the soluble fraction (vacuole) and the organelle in leaves was significantly reduced by hemin, which further reduced Cd toxicity. Furthermore, we found that hemin reduced TF and BCF in maize seedlings under Cd stress. This indicated that hemin could 
reduce $\mathrm{Cd}$ absorption and transportation in maize seedlings. The results showed that hemin reduced $\mathrm{Cd}$ toxicity by altering $\mathrm{Cd}$ 's chemical form and increased $\mathrm{Cd}$ retention in the root system by promoting the deposit of $\mathrm{Cd}$ on the root cell wall and the compartmentalization of the vacuole, which ultimately resulted in the reduction of $\mathrm{Cd}$ transport.

Secondary metabolites play an important role in regulating plant growth and responding to various biotic and abiotic stresses [60]. Cyclic hydroxamates are the main secondary metabolite in cereal plants, and their main substances include DIMBOA [61]. When destroyed by mechanical damage, insect pests, and pathogen invasion, plants will release activated DIMBOA [62-64]. Polyphenol is an important secondary metabolite, with antioxidant activity in plants [65]. As part of the plant defense system, polyphenols can effectively relieve the damage caused by free radical accumulation in plants [66]. As a key enzyme in phenylpropane metabolism, PAL has an important impact on plant secondary metabolism [67]. In this study, Cd treatment significantly reduced DIMBOA and total phenol contents and PAL activity in root and leaf, while hemin treatment increased DIMBOA and total phenol contents and PAL activity under Cd stress. This shows that exogenous hemin can improve the chemical defense response to $\mathrm{Cd}$ stress and improve the tolerance of maize seedlings.

\section{Conclusions}

Hemin promotes water status by improving root traits, root Lp, leaf RWC, and $\Psi_{\mathrm{w}}$ of maize. Hemin increases $\mathrm{Cd}$ deposition in maize root by improving chelation and subcellular distribution, and hemin reduces $\mathrm{Cd}$ absorption and transport, which contribute to reducing $\mathrm{Cd}$ concentration in maize seedlings. Moreover, hemin increases secondary metabolites in maize seedlings, which improves the chemical defense response to $\mathrm{Cd}$ stress (Figure 1). Therefore, exogenous hemin reduces the growth inhibition caused by $\mathrm{Cd}$ stress and enhances $\mathrm{Cd}$ tolerance of maize seedlings.

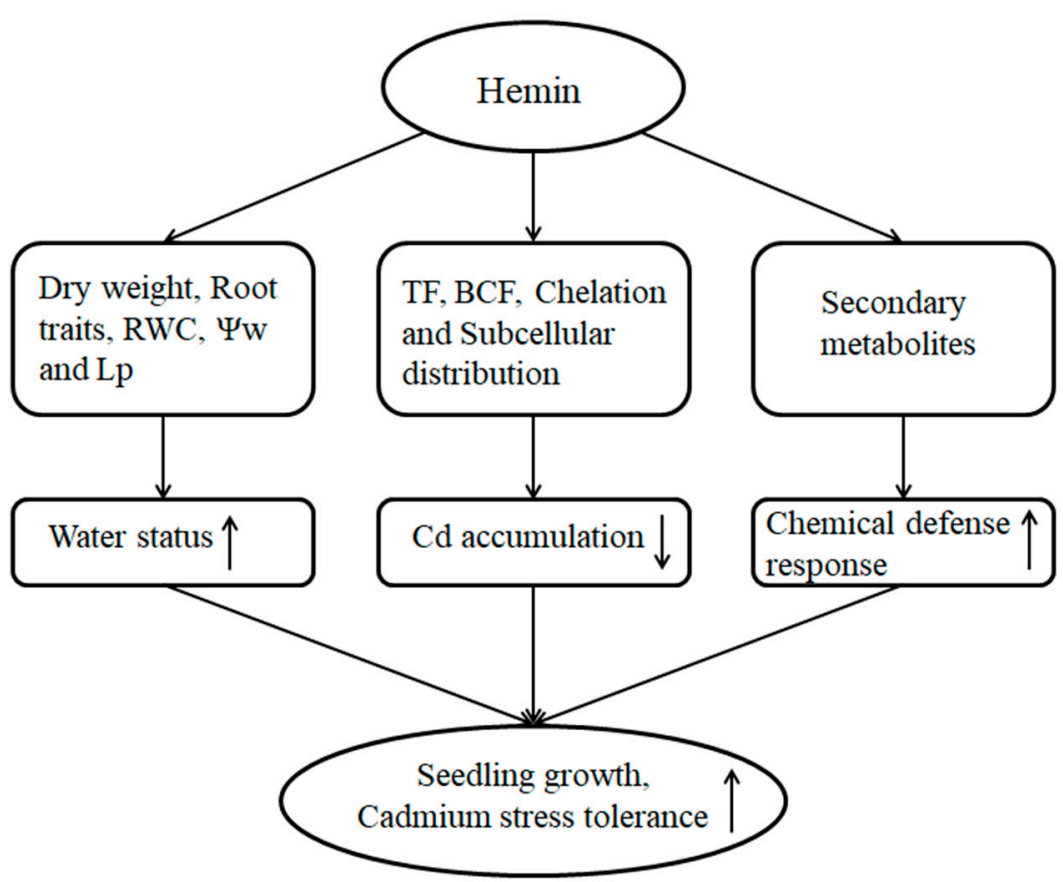

Figure 1. Schematic representation of the positive role of hemin on tolerance of maize to Cd stress. A model was developed to show that water status, $\mathrm{Cd}$ concentration, and chemical defense response were regulated by hemin in maize under Cd stress. The arrows $(\uparrow)$ and $(\downarrow)$ represent the positive and passive roles of hemin, respectively. 
Author Contributions: X.L. and Y.M. performed the entire experiment, analyzed the results, and drafted the manuscript. W.G. designed the entire experiment and was in charge of manuscript revisions. S.W. and W.G. interpreted the results and prepared the manuscript. All authors have read and agreed to the published version of the manuscript.

Funding: This research was funded by the National Key R\&D Program of China (Grant No. 2016YFD0300103 and 2017YFD0300506).

Institutional Review Board Statement: Not applicable.

Informed Consent Statement: Not applicable.

Data Availability Statement: Data sets analysed during the current study are available from the current author on reasonable request.

Acknowledgments: We thank Li Congfeng, Institute of Crop Sciences, Chinese Academy of Agricultural Sciences, for providing the experimental design and laboratory of this study.

Conflicts of Interest: The authors declare no conflict of interest.

\section{References}

1. Larson, C. China Gets Serious About Its Pollutant-Laden Soil. Science 2014, 343, 1415-1416. [CrossRef]

2. Luo, J.; Huang, J.; Zeng, D.; Peng, J.; Zhang, G.; Ma, H.; Guan, Y.; Yi, H.; Fu, Y.; Han, B.; et al. A Defensin-like Protein Drives Cadmium Efflux and Allocation in Rice. Nat. Commun. 2018, 9, 645. [CrossRef]

3. Wu, J.; Shi, Y.; Zhu, Y.; Wang, Y.; Gong, H. Mechanisms of Enhanced Heavy Metal Tolerance in Plants by Silicon: A Review. Pedosphere 2013, 23, 815-825. [CrossRef]

4. Kikuchi, T.; Okazaki, M.; Toyota, K.; Motobayashi, T.; Kato, M. The Input-output Balance of Cadmium in a Paddy Field of Tokyo. Chemosphere 2007, 67, 920-927. [CrossRef] [PubMed]

5. Zia-ur-Rehman, M.; Khalid, H.; Akmal, F.; Ali, S.; Rizwan, M.; Qayyum, M.F.; Iqbal, M.; Khalid, M.U.; Azhar, M. Effect of Limestone, Lignite and Biochar Applied Alone and Combined on Cadmium Uptake in Wheat and Rice under Rotation in an Effluent Irrigated Field. Environ. Pollut. 2017, 227, 560-568. [CrossRef] [PubMed]

6. Benavides, M.; Gallego, M.S.; Tomaro, M.L. Cadmium Toxicity in Plants. Braz. J. Plant Physiol. 2005, 17, 21-34. [CrossRef]

7. Chen, J.; Duan, B.; Xu, G.; Korpelainen, H.; Niinemets, U.; Li, C. Sexual Competition Affects Biomass Partitioning, Carbon-nutrient Balance, Cd Allocation and Ultrastructure of Populus cathayana Females and Males Exposed to Cd Stress. Tree Physiol. 2016, 36, 1353-1368. [CrossRef]

8. Lux, A.; Martinka, M.; Vaculik, M.; White, P.J. Root Responses to Cadmium in the Rhizosphere: A Review. J. Exp. Bot. 2010, 62, 21-37. [CrossRef] [PubMed]

9. Parmar, P.; Kumari, N.; Sharma, V. Structural and Functional Alterations in Photosynthetic Apparatus of Plants under Cadmium Stress. Bot. Stud. 2013, 54, 45. [CrossRef]

10. Mobin, M.; Khan, N.A. Photosynthetic Activity, Pigment Composition and Antioxidative Response of Two Mustard (Brassica juncea) Cultivars Differing in Photosynthetic Capacity Subjected to Cadmium Stress. J. Plant Physiol. 2007, 164, 601-610. [CrossRef]

11. Semane, B.; Dupae, J.; Cuypers, A.; Noben, J.P.; Tuomainen, M.; Tervahauta, A.; Karenlampi, S.; Van Belleghem, F.; Smeets, K.; Vangronsveld, J. Leaf Proteome Responses of Arabidopsis thaliana Exposed to Mild Cadmium Stress. J. Plant Physiol. 2010, 167, 247-254. [CrossRef] [PubMed]

12. Ni, J.; Wang, Q.; Shah, F.A.; Liu, W.; Wang, D.; Huang, S.; Fu, S.; Wu, L. Exogenous Melatonin Confers Cadmium Tolerance by Counterbalancing the Hydrogen Peroxide Homeostasis in Wheat Seedlings. Molecules 2018, 23, 799. [CrossRef] [PubMed]

13. Qu, D.; Gu, W.; Zhang, L.; Li, C.; Chen, X.; Li, J.; Li, L.; Xie, T.; Wei, S. Role of Chitosan in the Regulation of the Growth, Antioxidant System and Photosynthetic Characteristics of Maize Seedlings under Cadmium stress. Russ. J. Plant Physiol. 2019, 66, 140-151. [CrossRef]

14. Wagener, F.A.; Volk, H.D.; Willis, D.; Abraham, N.G.; Soares, M.P.; Adema, G.J.; Figdor, C.G. Different Faces of the Heme-heme Oxygenase System in Inflammation. Pharmacol. Rev. 2003, 55, 551-571. [CrossRef] [PubMed]

15. Becker, E.M.; Cardoso, D.R.; Skibsted, L.H. Quenching of Excited States of Red-pigment Zinc Protoporphyrin IX by Hemin and Natural Reductors in Dry-cured Hams. Eur. Food. Res. Technol. 2011, 232, 343-349. [CrossRef]

16. Sander, A.; Kretzer, S.; Bredt, W.; Oberle, K.; Bereswill, S. Hemin-dependent Growth and Hemin Binding of Bartonella henselae. FEMS Microbiol. Lett. 2000, 189, 55-59. [CrossRef] [PubMed]

17. Katoh, Y.; Nemoto, N.; Tanaka, M.; Takayama, S. Inhibition of Benzo[a] Pyrene-induced Mutagenesis in Chinese Hamster V79 Cells by Hemin and Related Compounds. Mutat. Res. 1983, 121, 153-157. [CrossRef]

18. Xie, Y.; Cui, W.; Yuan, X.; Shen, W.; Yang, Q. Heme Oxygenase-1 is Associated with Wheat Salinity Acclimation by Modulating Reactive Oxygen Species Homeostasis. J. Integr. Plant Biol. 2011, 53, 653-670. [CrossRef]

19. Han, Y.; Xuan, W.; Yu, T.; Fang, W.; Lou, T.; Gao, Y.; Chen, X.; Xiao, X.; Shen, W. Exogenous Hematin Alleviates Mercury-induced Oxidative Damage in the Roots of Medicago sativa. J. Integr. Plant Biol. 2007, 49, 1703-1713. [CrossRef] 
20. Chen, Q.; Gong, C.; Ju, X.; Zhu, Z.; Shen, W.; Shen, Z.; Cui, J. Hemin Through the Heme Oxygenase 1/Ferrous Iron, Carbon Monoxide System Involved in Zinc Tolerance in Oryza Sativa, L. J. Plant Growth Regul. 2018, 37, 947-957. [CrossRef]

21. Palacios-Rojas, N.; McCulley, L.; Kaeppler, M.; Titcomb, T.J.; Gunaratna, N.S.; Lopez-Ridaura, S.; Tanumihardjo, S.A. Mining Maize Diversity and Improving Its Nutritional Aspects within Agro-food Systems. Compr. Rev. Food Sci. F. 2020, 19, 1809-1834. [CrossRef] [PubMed]

22. Malcovska, S.M.; Ducaiova, Z.; Maslanakova, I.; Backor, M. Effect of Silicon on Growth, Photosynthesis, Oxidative Status and Phenolic Compounds of Maize (Zea mays L.) Grown in Cadmium Excess. Water Air Soil Poll. 2014, 225, 2056. [CrossRef]

23. Sun, K.; Yue, Y.; Wen, D.; Li, X.; Yang, Y.; Yang, N.; Zhang, H.; Chen, N.; Wang, K. Effects of Exogenous Sulfur on Maize (Zea mays L.) Growth and Cd Accumulation in Cd-contaminated Plastic Shed Soil. Environ. Monit. Assess. 2020, 192, 651. [CrossRef] [PubMed]

24. Zhu, Z.; Huang, Y.; Wu, X.; Liu, Z.; Zou, J.; Chen, Y.; Su, N.; Cui, J. Increased Antioxidative Capacity and Decreased Cadmium Uptake Contribute to Hemin-induced Alleviation of Cadmium Toxicity in Chinese Cabbage Seedlings. Ecotox. Environ. Safety 2019, 177, 47-57. [CrossRef]

25. Fu, G.; Zhang, L.; Cui, W.; Wang, Y.; Shen, W.; Ren, Y.; Zheng, T. Induction of Heme Oxygenase-1 with $\beta$-CD-hemin Complex Mitigates Cadmium-induced Oxidative Damage in the Roots of Medicago sativa. Plant Soil 2011, 345, 271-285. [CrossRef]

26. Cui, W.; Zhang, J.; Xuan, W.; Xie, Y. Up-regulation of Heme Oxygenase-1 Contributes to the Amelioration of Aluminum-induced Oxidative Stress in Medicago sativa. J. Plant Physiol. 2013, 170, 1328-1336. [CrossRef] [PubMed]

27. Li, L.; Gu, W.; Zhang, L.; Li, C.; Chen, X.; Qian, C.; Wang, Z.; Li, W.; Zuo, S.; Wei, S. Exogenous 2-(3,4-Dichlorophenoxy) Triethylamine Alleviates Salinity Stress in Maize by Enhancing Photosynthetic Capacity, Improving Water Status and Maintaining $\mathrm{K}+$ /Na+ Homeostasis. BMC Plant Biol. 2020, 20, 348. [CrossRef]

28. Jiang, H.; Zhang, J.; Han, Z.; Yang, J.; Ge, C.; Wu, Q. Revealing New Insights into Different Phosphorus-starving Responses between Two Maize (Zea mays) Inbred Lines by Transcriptomic and Proteomic Studies. Sci. Rep. 2017, 7, 44294. [CrossRef] [PubMed]

29. Salahuddin, M.; Nawaz, F.; Shahbaz, M.; Naeem, M.; Zulfiqar, B.; Shabbir, R.; Hussain, R. Effect of Exogenous Nitric Oxide (NO) Supply on Germination and Seedling Growth of Mungbean (cv. Nm-54) under Salinity Stress. Legume Res. 2017, 40, 846-852. [CrossRef]

30. Song, T.; Su, X.; He, J.; Liang, Y.; Zhou, T.; Liu, C. Selenium (Se) Uptake and Dynamic Changes of Se Content in Soil-plant Systems. Environ. Sci. Pollut. Res. 2018, 25, 34343-34350. [CrossRef]

31. Dumbrava, A.; Birghila, S.; Munteanu, M. Contributions on Enhancing the Copper Uptake by Using Natural Chelators, with Applications in Soil Phytoremediation. Int. J. Environ. Sci. Technol. 2015, 12, 929-938. [CrossRef]

32. Rama Devi, S.; Prasad, M.N.V. Copper Toxicity in Ceratophyllum demersum L. (Coontail), a Free Floating Macrophyte: Response of Antioxidant Enzymes and Antioxidants. Plant Sci. 1998, 138, 157-165. [CrossRef]

33. Li, D.; Chen, G.; Lu, Q.; Li, Y.; Wang, J.; Li, H. Responses of Two Kidney Bean (Phaseolus vulgaris) Cultivars to the Combined Stress of Sulfur Deficiency and Cadmium Toxicity. Biometals 2018, 31, 17-28. [CrossRef] [PubMed]

34. Cheng, Y.; Bao, Y.; Chen, X.; Yao, Q.; Wang, C.; Chai, S.; Zeng, J.; Fan, X.; Kang, H.; Sha, L.; et al. Different Nitrogen Forms Differentially Affect Cd Uptake and Accumulation in Dwarf Polish Wheat (Triticum polonicum L.) Seedlings. J. Hazard. Mater. 2020, 400, 123209. [CrossRef] [PubMed]

35. Mao, J.; Burt, A.J.; Ramputh, A.I.; Simmonds, J.; Cass, L.; Hubbard, K.; Miller, S.; Altosaar, I.; Arnason, J.T. Diverted Secondary Metabolism and Improved Resistance to European Corn Borer (Ostrinia nubilalis) in Maize (Zea mays L.) Transformed with Wheat Oxalate Oxidase. J. Agric. Food Chem. 2007, 55, 2582-2589. [CrossRef] [PubMed]

36. Sheng, K.; Shui, S.; Yan, L.; Liu, C.; Zheng, L. Effect of Postharvest UV-B or UV-C Irradiation on Phenolic Compounds and Their Transcription of Phenolic Biosynthetic Genes of Table Grapes. J. Food Sci. Technol. 2018, 55, 3292-3302. [CrossRef] [PubMed]

37. Wang, C.; Hu, D.; Liu, X.; She, H.; Ruan, R.; Yang, H.; Yi, Z.; Wu, D. Effects of Uniconazole on the Lignin Metabolism and Lodging Resistance of Culm in Common Buckwheat (Fagopyrum esculentum M.). Field Crop. Res. 2015, 180, 46-53. [CrossRef]

38. Shah, A.A.; Khan, W.U.; Yasin, N.A.; Akram, W.; Ahmad, A.; Abbas, M.; Ali, A.; Safdar, M.N. Butanolide Alleviated Cadmium Stress by Improving Plant Growth, Photosynthetic Parameters and Antioxidant Defense System of Brassica oleracea. Chemosphere 2020, 261, 127728. [CrossRef] [PubMed]

39. Liu, L.; Shang, Y.; Li, L.; Chen, Y.; Qin, Z.; Zhou, L.; Yuan, M.; Ding, C.; Liu, J.; Huang, Y.; et al. Cadmium Stress in Dongying Wild Soybean Seedlings: Growth, Cd Accumulation, and Photosynthesis. Photosynthetica 2018, 56, 1346-1352. [CrossRef]

40. Zadeh, R.; Arvin, S.M.J.; Jamei, R.; Mozaffari, H.; Nejhad, F.R. Response of Tomato Plants to Interaction Effects of Magnetic $\left(\mathrm{Fe}_{3} \mathrm{O}_{4}\right)$ Nanoparticles and Cadmium Stress. J. Plant Interact. 2019, 14, 474-481. [CrossRef]

41. Valentovicova, K.; Mistrik, I.; Zelinova, V.; Tamas, L. How Cobalt Facilitates Cadmium- and Ethylene Precursor-induced Growth Inhibition and Radial Cell Expansion in Barley Root Tips. Cent. Eur. J. Biol. 2012, 7, 551-558. [CrossRef]

42. Zhang, Z.; Liu, C.; Wang, X.; Shi, G. Cadmium-induced Alterations in Morpho-physiology of Two Peanut Cultivars Differing in Cadmium Accumulation. Acta Physiol. Plant. 2013, 35, 2105-2112. [CrossRef]

43. Xu, J.; Wang, W.; Yin, H.; Liu, X.; Sun, H.; Mi, Q. Exogenous Nitric Oxide Improves Antioxidative Capacity and Reduces Auxin Degradation in Roots of Medicago truncatula Seedlings under Cadmium Stress. Plant Soil 2010, 326, 321-330. [CrossRef]

44. Barcelo, J.; Cabot, C.; Poschenrieder, C. Cadmium-Induced Decrease of Water Stress Resistance in Bush Bean Plants (Phaseolus vulgaris L. cv. Contender) II. Effects of Cd on Endogenous Abscisic Acid Levels. J. Plant Physiol. 1986, 125, 27-34. [CrossRef] 
45. Chen, Q.; Zhang, X.; Liu, Y.; Wei, J.; Shen, W.; Shen, Z.; Cui, J. Hemin-mediated Alleviation of Zinc, Lead and Chromium Toxicity is Associated with Elevated Photosynthesis, Antioxidative Capacity; Suppressed Metal Uptake and Oxidative Stress in Rice Seedlings. Plant Growth Regul. 2017, 81, 253-264. [CrossRef]

46. Farooq, H.; Asghar, H.; Khan, M.; Saleem, M.; Zahir, Z. Auxin-mediated Growth of Rice in Cadmium-contaminated Soil. Turk. J. Agric. For. 2015, 39, 272-276. [CrossRef]

47. Zheng, S.; Wang, Q.; Yuan, Y.; Sun, W. Human Health Risk Assessment of Heavy Metals in Soil and Food Crops in the Pearl River Delta Urban Agglomeration of China. Food Chem. 2020, 316, 126213. [CrossRef]

48. Jin, Q.; Feng, J.; Sun, Y.; Cui, W.; Han, B.; Xu, S.; Shen, W.; Cui, J. Characterization of a Heme Oxygenase-1 from Tobacco That Is Involved in Some Abiotic Stress Responses. Int. J. Plant Sci. 2012, 173, 113-123. [CrossRef]

49. Li, H.; Jiang, M.; Che, L.; Nie, L.; Yang, Z. BjHO-1 is Involved in the Detoxification of Heavy Metal in India Mustard (Brassica juncea). Biometals 2012, 25, 1269-1279. [CrossRef] [PubMed]

50. Han, B.; Yang, Z.; Xie, Y.; Nie, L.; Cui, J.; Shen, W. Arabidopsis HY1 Confers Cadmium Tolerance by Decreasing Nitric Oxide Production and Improving Iron Homeostasis. Mol. Plant 2014, 7, 388-403. [CrossRef]

51. Han, Y.; Zhang, J.; Chen, X.; Gao, Z.; Xuan, W.; Xu, S.; Ding, X.; Shen, W. Carbon Monoxide Alleviates Cadmium-induced Oxidative Damage by Modulating Glutathione Metabolism in the Roots of Medicago sativa. New Phytol. 2008, 177, 155-166. [CrossRef] [PubMed]

52. Fang, Z.; Hu, Z.; Yin, X.; Song, G.; Cai, Q. Exogenous Glutathione Alleviation of Cd Toxicity in Italian Ryegrass (Lolium multiflorum) by Modulation of the Cd Absorption, Subcellular Distribution, and Chemical Form. Int. J. Environ. Res. Public Health. 2020, 17, 8143. [CrossRef] [PubMed]

53. Xue, M.; Zhou, Y.; Yang, Z.; Lin, B.; Yuan, J.; Wu, S. Comparisons in Subcellular and Biochemical Behaviors of Cadmium between Low-Cd and High-Cd Accumulation Cultivars of Pakchoi (Brassica chinensis L.). Front. Environ. Sci. Eng. 2014, 8 , 226-238. [CrossRef]

54. Mendoza-Cozatl, D.G.; Moreno-Sanchez, R. Control of Glutathione and Phytochelatin Synthesis under Cadmium Stress. Pathway Modeling for Plants. J. Theor. Biol. 2006, 238, 919-936. [CrossRef] [PubMed]

55. Hou, M.; Li, M.; Yang, X.; Pan, R. Responses of Nonprotein Thiols to Stress of Vanadium and Mercury in Maize (Zea mays L.) Seedlings. Bull. Environ. Contam. Toxicol. 2019, 102, 425-431. [CrossRef] [PubMed]

56. Hall, J.L. Cellular Mechanisms for Heavy Metal Detoxification and Tolerance. J. Exp. Bot. 2002, 53, 1-11. [CrossRef]

57. Fu, X.; Dou, C.; Chen, Y.; Chen, X.; Shi, J.; Yu, M.; Xu, J. Subcellular Distribution and Chemical Forms of Cadmium in Phytolacca americana L. J. Hazard. Mater. 2011, 186, 103-107. [CrossRef] [PubMed]

58. Vatehova-Vivodova, Z.; Kollarova, K.; Malovikova, A.; Liskova, D. Maize Shoot Cell Walls under Cadmium Stress. Environ. Sci. Pollut. Res. 2018, 25, 22318-22322. [CrossRef]

59. Wu, X.; Song, H.; Guan, C.; Zhang, Z. Boron Alleviates Cadmium Toxicity in Brassica napus by Promoting the Chelation of Cadmium onto the Root Cell Wall Components. Sci. Total Environ. 2020, 728, 138833. [CrossRef]

60. Singh, A.K.; Dhanapal, S.; Yadav, B.S. The Dynamic Responses of Plant Physiology and Metabolism during Environmental Stress Progression. Mol. Biol. Rep. 2020, 47, 1459-1470. [CrossRef]

61. Niemeyer, H.M. Hydroxamic Acids (4-Hydroxy-1,4-benzoxazin-3- ones), Defence Chemicals in the Gramineae. Phytochemistry 1988, 27, 3349-3358. [CrossRef]

62. Rollo, D.; Borden, J.H.; Casey, I.B. Endogenously Produced Repellent from American Cockroach (Blattaria: Blattidae): Function in Death Recognition. Environ. Entomol. 1995, 24, 116-124. [CrossRef]

63. Cuevas, L.; Niemeyer, H.M.; Jonsson, L.M.V. Partial Purification and Characterization of a Hydroxamic Acid Glucoside $\beta$-dglucosidase from Maize. Phytochemistry 1992, 31, 2609-2612. [CrossRef]

64. Hofman, J.; Hofmanova, O. 1, 4-Benzoxazine Derivatives in Plants. Eur. J. Biochem. 1969, 8, 109-112. [CrossRef] [PubMed]

65. Tufarelli, V.; Casalino, E.; D'Alessandro, A.G.; Laudadio, V. Dietary Phenolic Compounds: Biochemistry, Metabolism and Significance in Animal and Human Health. Curr. Drug Metab. 2017, 18, 905-913. [CrossRef] [PubMed]

66. Tusevski, O.; Stanoeva, J.P.; Stefova, M.; Spasenoski, M.; Simic, S. State of Antioxidant Systems and Phenolic Compounds' Production in Hypericum perforatum L. Hairy Roots. Acta Physiol. Plant. 2019, 41, 132. [CrossRef]

67. Wang, C.; Lu, J.; Zhang, S.; Wang, P.; Hou, J.; Qian, J. Effects of Pb Stress on Nutrient Uptake and Secondary Metabolism in Submerged Macrophyte Vallisneria natans. Ecotox. Environ. Safety 2011, 74, 1297-1303. [CrossRef] [PubMed] 